\title{
The Causes of Bureaucratic Petty Corruption in the Province of Aceh in Indonesia
}

\author{
Muhammad bin Abubakar \\ Magister Program in Public Administration, Faculty of Social and Political Sciences, Universitas Malikussaleh, \\ Aceh Utara, Indonesia. \\ *Corresponding Author: mabubakar@unimal.ac.id
}

\begin{abstract}
This article tried to explain the causes of petty corruption in the Province of Aceh. It took the kleptocratic approach and Patrimonialism Politics model in explaining the causes of corruption in the region. It had utilized extensively the secondary sources data from books, journal articles and local media report. It found that after the end of the conflict, Aceh was captured by the local kleptocratic elite and they have been effectively used the patrimonialism politics in maintaining their hegemony and protect their group interest. Leaving the region as the state of being one of the poorest region in Indonesia.
\end{abstract}

Key words: corruption; kleptocractic; patrimonialism;

\section{Introduction}

This article explores factors that cause perpetuation of petty corruption in the Aceh after the endorsement of law on local government in Indonesia with special emphasis on the impact of the kleprocratic elites and politics of neo-patrimonialism in the central government on the local politics and the prevalence of corruption in Aceh.

The proponent of kleptocratic approach argued that corrupt is due to the selfishness and greediness of the leader who used political power for his personal enrichment (Andreski, 1968). The kliptocrat leader, in the pursuance of self -enrichment, might set up a political system that could maximize the economic interest of himself and his loyalist elite group. They act like a private monopolist that strives for productivity efficiency, while restricting the output of monopoly so that their profit could be maximized (Olson, 1993). They do formulate laws and regulations, such as taxes, subsidies and even privatisation, but these regulations are not for the necessities of the welfare of the public at large, rather to maximise their own profits (Ackerman, 1999). However, not all kleptocrats want a strong role of state in economy. Some kleptocrats prefer to open market system and liberalize the economy to increase the productivity of the country. As the productivity of the country increases that might also increase their profit, for in kleptocratic state, there is no perfect market as such (Ibid). Those kleptocrats would make sure that the system work for their own benefit. The kleptocrats could manipulate contract and the process of privatisation of state-own enterprises. They might award the contract and privatisation to party who is willing pay highest bribe to public official, or in return of the award of privatisation and contracts, the official might oblige the winner of the tender to have partnership with local companies belong to their families or close friend (Ibid).

Furthermore, the kleptocrat often practiced the so called politics of neo-patrimonialism as the way to maintain the control of political power. This concept is originated from Weber's concept of patrimonilism which tries to explain a pattern of political system where the power of the leader derived primarily from his ability to manipulate political condition to win and retain the loyalty of dominant section of the political elite. It is assumed that politics is characterized by elite-rival factions and cliques whom principally competing for obtaining influence and the distribution of spoil, in such condition, for the patrimonialist leader to remain in power is by satisfying the 
material interest of this particular segment of political elite especially through the distribution of privileges, such as fiefs and benefices (King, 2000).

Moreover, there is no separation of the "private" and the "public sphere", in such political setting; therefore it might perpetuate the practice of extortion on a mass-scale basis. Rent-seeking behaviour is not legally condemned as corruption, rather it is encouraged by the existing norms (Lenski and Lenski, 1987); in return to their loyalties to the ruling elite. Hence, corruption might serve as an effective mean for political stability and particular for the ruler to remain in power (Klitgaard, 1999). These two approaches are very useful for analysing the problem of corruption in Aceh in particular. It addresses question how does Kleptocrat Elite abused it political power and state governance for his own interest and cronies. Also it addresses question how Politics of NeoPatrimonialism maintained Elite political control on the local government of Aceh to protect the interest of their group and cronies.

\section{The Impact of the Kleptocratic Leader and Politics of Neo-Patrimonialism}

The end of the New Order regime did not reduce corruption (Munggoro et.all, 1999) 1; it rather remained endemic during the post Suharto regime- a bureaucratic-authoritarian regime. Corruption had become worse; Local elite (mostly ex-Gerakan Aceh Merdeka combatants/ GAM) gradually emerged as an authoritarian ruler and kleptocrat elite, resembling the ancient Javanese rulers who distributed national resources to family members and other cronies for remaining in power (Alatas, 1990). ${ }^{2}$

Lorem ipsum dolor sit amet, consectetuer adipiscing elit. Maecenas porttitor congue massa. Fusce posuere, magna sed pulvinar ultricies, purus lectus malesuada libero, sit amet commodo magna eros quis urna. Nunc viverra imperdiet enim. Fusce est. Vivamus a tellus. Pellentesque habitant morbi tristique senectus et netus et malesuada fames ac turpis egestas. Proin pharetra nonummy pede (Zurlo et al., 1990). Mauris et orci. Aenean nec lorem. In porttitor. Donec laoreet nonummy augue. Suspendisse dui purus, scelerisque at, vulputate vitae, pretium mattis, nunc. Mauris eget neque at sem venenatis eleifend (Myers et al., 2002). Ut nonummy. Fusce aliquet pede non pede. Suspendisse dapibus lorem pellentesque magna. Integer nulla. Donec blandit feugiat ligula. Donec hendrerit, felis et imperdiet euismod, purus ipsum pretium metus, in lacinia nulla nisl eget sapien.

The New local regime was concerned with the problem of underdevelopment and political instability. The answer to this problem was by initiating a total restructuring policy that emphasized security, stability and economic development. The ex-combatant elite use of their former para military as a strong backbone of his regime. They took part in politics through the local based political party -Aceh Party/ Partai Aceh (PA) ${ }^{3}$-- side by side the senior bureaucratic and technocrats, particularly in the decision-making process in Aceh. The involvement of the exGAM in politics and civil administration had strengthened the former GAM leaders' control over state enterprises like it was during the Suharto regime whereby state enterprises were controlled by the military and rendered military power absolute. Harold Crouch states:

After 1966, Suharto gradually tightened his hold on the armed forces... with appointments to civil posts that offer prospects of material gains. [While] other officers were encouraged to go into business, with the promise of help from the administration...licenses, credits, or contract.... (Crouch in Kohli, 1986).

\section{The Patrimonial System of Administration: An Opportunity for Corruption}

\footnotetext{
${ }^{1}$ Corruption was an important factor that led the Old Order to collapse, especially when Sukarno introduced the so-called guided democracy coupled with a defensive policy (politik banteng), where the state monopolized the state economy and nationalised all foreign assets. The policy had caused a serious inflation in the modern Indonesian history, which reach almost $1000 \%$. Inflation had significantly affected the live of the public officials and the people at large. In order to maintain a decent life-style, public officials were involved in rent-seeking activities, making corruption almost endemic in the country.

${ }^{2}$ It was practiced in the pre-modern history of Indonesia, that king was in the exalted position with an ultimate political authority to dispense personal favour to his own family or loyal supporters.

${ }^{3}$ The PA is a local party that was established after the Helsinki Peace Agreement between the Indonesia Government and The GAM in Helsinki in August $5^{\text {th }}$ 2005. During two consecutive Local Representative Assembly Election the won major sits in almost all districts in Aceh.
} 
The restructuring policy had profound effects on governmental administration as a whole and ultimately on corruption. Under former GAM combatants, the appointment of many of local highranking bureaucrats, and directors of state-owned enterprises has to have closed connection and consent of the local GAM elite. As it was practiced in the past, these officers had the opportunity to enrich themselves while they were holding these positions. By rewarding these officers with economic favors, politically the GAM elites benefited a lot, because they would not rebel against him, instead remained politically loyal to him (see Ross in Drysdale, 2000). He also rewarded those loyal bureaucrats and technocrats with special privileges to earn extra incomes from the public purse by marking up price of commodities in the procurement of public office and public development project. While for the ordinary civil servant were allowed to take in rent-seeking activities and demanded illegal administrative fee for any services rendered to the public. This new elite had never considered rent-seeking activities in the public services as corruption, as long as it was properly done and did not disturb the security, stability and development of the country, corruption was alright. The GAM elites played a dominant role in awarding contracts, licenses and developmental projects. The Ali Baba economy had mutually benefited them, it is very a copy of the business practice when Suharto still power. Perhaps, it is the business culture that was inherited through generation (Liddle, 1997).

Another significant impact of patrimonial system of administration is the prevalence of petty corruption at all levels of government administration. this is due to the incapability of the public servant to make a distinction between public affairs and personal affairs, in which most of the time the official mixes up the two affairs together (alatas, 19990). the inability of the public officials to differentiate between the two spheres is strongly associated with the innate culture of the society from which these public officials are from. king argues that, at the individual level, the basic source of this problem is the conflict between the legal norms of the government bureaucracy and the folk norms that various people share in the society - the norm that governs various informal social networks, such as kinship ties, cronyism and patron-client (kng, 2000).

Therefore, it depends on the individual's conformity with either one of the two norms. If the folk norms are more dominant than the legal norms, corruption certainly became prevalent. It is due to the practice of particularlism and instrumentalism - the two components underlying most sets of the folk norms. Lee further explains that, on the one hand, the practice of particularism might result in favorable or special treatment of "insider" at the expense of fairness and honesty to the "outsider"; while on the other the practice of instrumentalism, where the realization of personal goals with a minimum cost, regardless of legality of the means used to achieve those goals (Lee, 1986). Such assumption is very much relevant to the case of bureaucratic system in Indonesia, which seems to have been set in such away that the legal norms is only for the formality, while the folk norms has been predominantly regulating the behavior of the bureaucrats at all level of government. In such bureaucratic system, corruption becomes the reality of life and as the way to survive.

In addition to patrimonialist approach, the "fair wage-effort hypothesis", assumed that petty corruption becomes prevalent is due to the socil condition in which civil servants earn relatively lower than the level of satisfactory payment; and therefore, they tend to engage in "satisficing" rather than "maximizing" behavior. They involve in corruption to achieve a "fair" income, and therefore if they receive proper or fair payment, they certainly may let go the chance to practice corruption (Weder, 1997).

As in other parts of Indonesia, the impact of the patrimonial system of government on the local politics in Aceh in particular was obvious. The birth of new Ulëëbalang group who were former GAM combatants foreseen the important of having good relation with the Ulama as the catalyst of communalism within the Acehnese community and that has weakened the domination of central government in the local politics. The new Ulëëbalang group enjoyed wide range of socio-political and economic privileges. They close their eyes on impact of unscrupulous civil servant who were involved in rent-seeking activities for self-enrichment on the local development as along as it did not disturb their group interests. Such permissive attitude was an effective tool for controlling the civil servants so that they remain loyal to his government. It created a paternalisatic style of 
leadership whereby the children were expected to show loyalty to make the father happy: "asal bapak senang" to use the term that was popular during the Suharto's era. As a result, the problem of corruption began to encroach into the local politics of Aceh.

Thus, by combining the above two approaches two sets of conditions might be considered as reliable determinant factors contributing to the perpetuation of the petty corruption in the public sector in Aceh in particular. The first set of condition is pertaining to the social-economic status of the public officials. Particularly before reformation and the fall of Suharto, the salaries of public official were notoriously low, making them unable to keep pace with the cost of living especially in the major cities.

Despite of the notoriously low salary, the public official is considered as a highly prestigious profession and possesses considerable discretionary power; and therefore they are expected by the society to maintain a commensurately prestigious way of life, and generously provide assistance and support to their kins, friends and subordinates in time of need, such as authoritative back up and financial support. Such a combination of the low salary and considerable discretionary power creates a feeling of personal discrepancy and paradox of role; and that ignites the feeling of the needs to match their prestige and power that they possess. In order to match these two paradoxes, some official might resort to rent-seeking activities for additional income to maintain a high standard of living, while for those who maintain their idealism and professionalism they find their way through self employment such as farming, opening a restaurant, or other legal business activities, however the number of such people are few.

Another set of condition which contributes to the prevalence of petty corruption is very much structural and institutional in nature. The public officials in Indonesia consider themselves as the governing elite, more as masters than as servants. Such perception might be inherited from the colonial period or from the traditional practice of administration in the history of this nation. For instance the traditional system of aristocracy which was perceived as the lord (King, 2000). The PA used to win normally 70 to 75 per cent of the vote in the regular general elections. In such administrative system, a culture of unity and reciprocal benefits was established, instead of distance and autonomy between politicians and the bureaucracy Kristiansen and Ramli 2006).

As the result, it created gaps between the bureaucracy and the public. Thus, as long as the public official maintains such perception of their position as the aristocrat class of the past certainly petty corruption remains as part of the rules of the game in public administration. The public continues to provide the fee for any administrative service received

\section{Petty Corruption and the Kleptocratic Bureaucrats in Aceh}

As in other regions in Indonesia, petty corruption in the civil service was also prevalent in Aceh. The civil service had become a business firm for the civil servants for maximizing their income and self-enrichment. As generally agreed upon that interacting with administration is considered to be slow and may take times due to long bureaucratic requirements. Civilians had to provide additional fees for settling administrative matters from birth registrations to death registrations. Petty money became practical necessity for getting things done faster in business and politics. If one followed the formal line the process may be delayed or requested to fulfil a long list of requirements. By joining faster line with a few thousand of Indonesian Rupiah the matter might be processed faster and there was no need for completing the long list of requirements. For instance, to get an identity card, without fee it might take a week to get it done, by joining the express line it might take only one hour or a day to get it dine. Similarly, to get a driving licence, the formal line required a long list of requirements including regulations test and driving test. By join express line, it might be ready within an hour or two, without having to sit for any test.

In addition to that, long bureaucracy and being far way from the centre district administration, there emerges of worms or middlemen (Ulat or calo) in the government offices, who offered faster service to the client who might be busy businessman or impatient civilians.4 These agents acted as mediators between the clients and the officer in charge. After the job was done, the clients usually paid some amount of fees to the agents. Such corrupt practice was

${ }^{4}$ Although, there are fosters that state "Jangan melalui Calo", "Kawasan Bebas Korupsi dan Pungli" 
common in the matters related for the processing business license, road tax extension and passport. For instance, to get a passport, through formal line it costs not more than Rp 150.000 to 280.000; by joining express line through the agent the cost might rise up, depends on the agreement between the agent and clients. The existence of faster line for settling the matters contributed to mutual benefits between mostly the rich people and officers in charge. The rich people would bribe the civil servants to make regulations works for his interest, and the officers would maximise their income from the transaction.

\section{Conclusions}

The practice of neo-pratimonial system of government by a kleptocratic leadership had significantly contributed to the prevalence of corruption in the region. The existent of former GAM combatants, as the backbone of local administration, in the politics and economy, making transparency and accountability almost impossible in the state administration. Moreover, the domination of PA's Elite in local administration as the Governor, Head District and Local Legislative Assemlby forced civil servants to support this political party, PA. Having control of local the Legislative Assembly and local government levels, they had created a cooperation between the military, former combatants, bureaucrats and business world in governing the country. Many high rank officers who had connection with GAM elites were posted in the public offices, from the post of a Secretary of Region to the lower post of chief of the village. As it was practiced in the previous regime, they continued to take part in the rent seeking activities in term of issuance of business licenses and tenders. Some of them jointly cooperated with Chinese business tycoon in the form of Ali Baba corporations or played as a kick-back or protector of the Chinese business sites.

in addition, the practice of nepotism and cronyism was so rampant at the regional and local government. the position and recruitment at the public office was openly declared but the final has to be table before the local gam elites. it had become their privileges that only their family members and close associate has the access to such recruitment. despites of it had become the public secret that the local enforcement, executive and assemblymen had abused their authority and embezzled public fund for their own enrichment, still hard to find evidence for corruption. consequently, the promise for development and people welfare had never been realized, instead aceh has been ranked for several consecutive years as one of the poorest region in Indonesia.

\section{References}

Andreski, Stanislav, (1968). Privately provided public goods in a large economy: The limits of altruism", in The African predicament: A study in the pathology of modernization, ed. Stanislav Andreski: New York: Atherton.

Caroline V. Rijckeghem and Beatrice Weder. (1997). Corruption and the Rate of Temptation: do low wages in the civil services cause corruption, IMF Working Paper.

Dani W. Munggoro (1999). Mengugat industri pertambangan di Indonesial. Bogor: LSPP, Walhi, Latin dan Pikul.

Dwight Y King. (2000). Corruption in Indonesia: A curable cancer?" Journal of International Affairs, vol. 53, issue 2, (Spring 2000 a): 603-625.

Gerhald E. Lenski and Jean Lenski (1987). Human Societies: An Introduction to Sociology (New York: McGraw Hill, Inc, 5th edn.

Harold Crouch (1986). Patrimonialism and Military Rule in Indonesia," in The State and Development in the Third Word, ed., Atul Kohli (US: Princeton University Press.

Kingsbury. D. \& Aveling. H. (eds.). (2004). Autonomy and disintegration in Indonesia. London: Routledge Curzon.

Ledivina V. Carino(Quezon City: JMC Press 1986) .

McLeod, Ross. (2000). Government-Business Relations in Indonesia" in Reform and recovery in East Asia: The role of the state and economic enterprise, ed., Peter Drysdale. London: Routledge.

Olson, Mancur, (1993). Dictatorship, democracy, and Development," American Political Science Review, vol. 87: 567-575.

Rance P.L. Lee, Bureaucratic corruption in Asia: The problem of incongruence between legal norms and folk norms" in Bureaucratic Corruption in Asia, ed. 
Robert, Klitgaard (1998). Corruption: Beyond shame, apathy, futility", paper presented at the book launch of Membasmi korupsi, Jakarta September 17.

Stein Kristiansen and Muhid Ramli (2006). Buying an income: the market fro civil service positions in Indonesia," Contemporary Southeast Asia, 28.2 (August 2006), pp. 207-228

Susan Rose-Ackerman (1999). Corruption and Government: Causes, Consequences, and Reform (Cambridge: Cambridge University Press.

Syed Hussein Alatas (1990). Corruption: Its nature, causes and Function. Kuala Lumpur: S. Abdul Majeed.

William R. Liddle (1997). Leadership and culture in Indonesian politics. Australia: Allen \& Unwin. 